\title{
In vivo anti-inflammatory activity of rhizome of Drynaria quercifolia (L.) J. Sm.
}

\author{
Research Article
}

\section{Greshma P Raj ${ }^{*}$, Shincymol V V², Ansary P Y ${ }^{3}$, Sara Moncy Oommen ${ }^{4}$}

\author{
1. P G Scholar, 2. Associate Professor, 3. Professor \& HOD, Department of Dravyaguna Vijnanam, \\ Government Ayurveda College, Tripunithura, Ernakulam, Kerala, India. \\ 4. Professor \& HOD, Department of Dravyaguna Vijnanam, Govt. Ayurveda College, Kannur, Kerala, India.
}

\begin{abstract}
Inflammation is found as a common pathogenic process in many of the chronic diseases. To manage them drugs having multiple active principles is needed. Here comes the importance of easily available, potent herbal medicines. Drynaria quercifolia (L.) J. Sm., is a medicinal fern and its rhizome is an ingredient of some Ayurvedic formulations with inflammation. Through present study in vivo analysis of powder (choorna) of the drug were done. Wistar Albino rats were used for the purpose. One group was control (no treatment) and the other three were treated groups given with the suspension of powdered drug in half the calculated effective dose $(0.108 \mathrm{gm} / 200 \mathrm{gm} \mathrm{b}$. Wt. $)$, calculated effective dose $(0.216 \mathrm{gm} / 200 \mathrm{gm} \mathrm{b}$. Wt. $)$ and double the calculated effective dose $(0.432 \mathrm{gm} / 200 \mathrm{gm} \mathrm{b}$. Wt. $)$. Repeated measures ANNOVA with Tukey's post hoc analysis was used as statistical tool to analyse results within the group and one way ANNOVA with Tukey's post hoc analysis was used for between group analysis. In all the three treated groups significant reduction in paw oedema noted at $2^{\text {nd }}$ hour and maximum reduction at $4^{\text {th }}$ hour after drug administration. But a highly significant reduction in paw oedema at shortest time after drug intake was produced by group administered with double the calculated effective dose of the drug. This showed dose dependent anti-inflammatory action of powder of rhizome of Drynaria quercifolia (L.) J. Sm. This activity can be due to the presence of anti-inflammatory phytoconstituents in the rhizome such as naringin, quercetin, friedelin, betasitosterol, etc.
\end{abstract}

Key Words: Inflammation, Ayurvedic, Fern, Herbal, Choorna, Naringin.

\section{Introduction}

The prevalence of chronic diseases that leads to morbidity and mortality is increasing now a days. Most of such disease are not single entities as they exists with several etiological factors and different pathological process (1). Common pathogenesis common in many chronic diseases is inflammation (2). Drugs having multiple active principles is the best option in order to tackle the multiple target and that therapies should be in a balanced and personalized to avoid adverse reactions (1). Here comes the importance of Ayurveda and its holistic approach in disease management.

In Ayurvedic system of medicine, diseases management is mainly by utilizing the medicinal power of plants and most of them belongs to gymnosperm and angiosperm divisions. But, over exploitation makes their scarcity and reduced land availability makes difficulty in cultivating them. So scientific exploration of therapeutic potential of other divisions like pteridophytes is need of the time. Drynaria quercifolia (L.) J. Sm. is such an important pteridophyte having

\section{* Corresponding Author:}

\section{Greshma P Raj}

PG Scholar,

Department of Dravyaguna vijnanam,

Governemnt Ayurveda College, Tripunithura,

Ernakulam, Kerala, India.

Email Id: greshmapraj@gmail.com medicinal value described Hortus Malabaricus, a compilation work on medicinal plant wealth of Kerala (3). In northern part of Kerala the plant is known by the name Thudinthappala and its rhizome is being used as ingredient of formulations of external application like Ellumnisadi choorna (4). Use of its rhizome as food and medicine among tribal in different parts of the country also reported (5).

Antioxidant (6), antiarthritic (7), antipyretic (8), antibacterial (9) and anti-inflammatory (10) activities of various extracts of the rhizome was also evaluated through in vitro and in vivo methods. But the evaluation of the drug in Ayurvedic dosage forms is not available. So the present study aimed on in vivo analysis of antiinflammatory activity of orally administered rhizome powder (choorna) of Drynaria quercifolia (L.) J. Sm.

\section{Materials and Methods Materials}

12 female and 12 Male Wistar Albino rats weighing 150 to $200 \mathrm{gm}$, suspension of the drug, Formalin, Plethysmometer, feeding bottles, beaker, weighing machine, permanent marker, feeding cannula, rat cages, syringes $1 \mathrm{ml}$.

\section{Procurement of animals}

From the proposed source, College of Veterinary and Animal Sciences, Mannuthy, Thrissur, Kerala (Reg. No. 328/GO/Re/S//01/CPSEA) 12 female and 12 male Wistar Albino rats were procured. They were acclimatized by keeping in animal house of 
Greshma P Raj et.al., In vivo anti-inflammatory activity of rhizome of Drynaria quercifolia (L.) J. Sm.

Department of Dravyagunavijnanam, Government Ayurveda College, Tripunithura for 7 days before use.

\section{Dose fixation}

There is no classical reference available regarding the dose of choorna (powder) of rhizome Drynaria quercifolia (L.) J. Sm. As per the references in Sarangadhara Samhita, $12 \mathrm{gm}$ is the dose of choorna (powder) for adult (11). Using Paget and Barnes table, the effective dose of the powdered drug for rats was calculated (conversion factor 0.018 for 200 gm body weight rats) (12) $.0 .216 \mathrm{gm}$ was found as the calculated effective dose for rat of $200 \mathrm{gm}$ body weight. Dose of Formalin used was $0.05 \mathrm{ml}$.

\section{Preparation of choorna (powder) for the study}

A suspension of the drug was prepared by mixing $12 \mathrm{gm}$ powder in $100 \mathrm{ml}$ of distilled water. So $0.12 \mathrm{gm}$ of the powdered drug was available in $1 \mathrm{ml}$ of suspension. The volume of suspension administered to a rat of 200 gm body weight in half the calculated effective dose, calculated effective dose and double the calculated effective dose was $0.9 \mathrm{ml}, 1.8 \mathrm{ml}$ and $3.6 \mathrm{ml}$ respectively.

\section{Mode of administration}

Through oral route suspension of the powdered drug was administered to the rats. Formalin was administered in the form of sub cutaneous injection in the left hind limb paw of the rats.

\section{Dosing schedule}

Single time administration was done for all the groups through oral route.

\section{Grouping of animals}

24 Wistar Albino rats were divided into 4 groups viz Group A (Control- no treatment), Group B (half the calculated effective dose group), $\mathrm{C}$ (calculated effective dose group) and D (double the calculated effective dose group). Each group contained 6 rats (3 females, 3 males). (Table 1)

\section{Table 1: Grouping of animals for anti-inflammatory activity \\ Group \\ Drug Dose}

Group A- control (No treatment)

Group B- half the calculated effective dose

Group C- the calculated effective dose

Group D- double the calculated effective dose
Distilled water $(2 \mathrm{ml} / 200 \mathrm{~g}$ b. Wt $)$

$1 / 2 \mathrm{X}(0.108 \mathrm{gm} / 200 \mathrm{gm}$ b. Wt. $)$

$\mathrm{X}(0.216 \mathrm{gm} / 200 \mathrm{gm} \mathrm{b}$. Wt. $)$

$2 \mathrm{X}(0.432 \mathrm{gm} / 200 \mathrm{gm}$ b. Wt. $)$

\section{Methods: Formalin-induced paw oedema model}

Food was withdrawn 12 hours before the start of experiment and resumed after completion of experiment. A mark was made on the left hind paw of the weighed rat just beyond tibio-tarsal junction so that every time the paw was dipped in the water column of plethysmometer up to fixed mark to ensure constant paw volume. To ensure uniform hydration, rats were given with $5 \mathrm{ml}$ of distilled water by stomach tubes before the start of experiment. Normal paw volume of left hind limb of rats were noted before formalin injection. $0.05 \mathrm{ml}$ of formalin was injected subcutaneously into left hind limb paw of rat $30 \mathrm{~min}$ after the oral administration of water to induce acute inflammation. Rats with a minimum of $0.4 \mathrm{ml}$ increase in the normal paw volume were selected for the study. The non-inflamed right paw served as reference for comparison. The respective doses of suspension of powdered drug was administered orally using feeding cannula to animals in each group. Paw volume were recorded at every 1 hour up to $4^{\text {th }}$ hour after drug administration. Changes in paw volume by comparing the values before and after the administration of the powdered drug and the values of the control with the treated groups were used for statistical analysis.

\section{Ethics}

Approval from the institutional animal ethics committee was obtained and the number was No B4/2601/2017/AVC.

\section{Results}

A comparison was done in paw volume in Group A (Control (no treatment)), Group B (Half the calculated effective dose), Group C (Calculated effective dose) and Group D (Double the calculated effective dose) between before drug administration (BDA) and after drug administration at every 1 hour up to $4^{\text {th }}$ hour. Paw volume was again compared between every 1 hour up to $4^{\text {th }}$ hour separately in all the above groups. The difference in paw volume was also compared between all the groups at before drug administration and after drug administration at every 1 hour up to $4^{\text {th }}$ hour.

In Group A (Control (no treatment)) a highly significant increase in paw volume was noted after the administration of distilled water compared to the paw volume before distilled water administration. (Table 2)

Table 2: Comparison of paw volume within Group A (Control (no treatment))

\begin{tabular}{|c|c|c|c|c|c|}
\hline Group A & Mean Diff. & $\mathbf{q}$ & Significance & Summary & 95\% CI of diff \\
\hline BDA Vs $1^{\text {st }} \mathrm{hr}$ & -0.1167 & 6.931 & Yes & $* * *$ & -0.1879 to -0.04543 \\
\hline BDA Vs $2^{\text {nd }} \mathrm{hr}$ & -0.2000 & 11.88 & Yes & $* * *$ & -0.2712 to -0.1288 \\
\hline BDA Vs $3^{\text {rd }} \mathrm{hr}$ & -0.3167 & 18.81 & Yes & $* * *$ & -0.3879 to -0.2454 \\
\hline BDA Vs $4^{\text {th }} \mathrm{hr}$ & -0.4167 & 24.75 & Yes & $* * *$ & -0.4879 to -0.3454 \\
\hline $1^{\text {st }} \mathrm{hr} \mathrm{Vs} 2^{\text {nd }} \mathrm{hr}$ & -0.08333 & 4.951 & Yes & $*$ & -0.1546 to -0.01210 \\
\hline $1 \mathrm{st} \mathrm{hr} \mathrm{Vs} 3^{\text {rd }} \mathrm{hr}$ & -0.2000 & 11.88 & Yes & $* * *$ & -0.2712 to -0.1288 \\
\hline $1^{\text {st }} \mathrm{hr} \mathrm{Vs} 4^{\text {th }} \mathrm{hr}$ & -0.3000 & 17.82 & Yes & $* * *$ & -0.3712 to -0.2288 \\
\hline $2^{\text {nd }} \mathrm{hr} V s 3^{\text {rd }} \mathrm{hr}$ & -0.1167 & 6.931 & Yes & $* * *$ & -0.1879 to -0.04543 \\
\hline $2^{\text {nd }} \mathrm{hr} \mathrm{Vs} 4^{\text {th }} \mathrm{hr}$ & -0.2167 & 12.87 & Yes & $* * *$ & -0.2879 to -0.1454 \\
\hline $3^{\text {rd }} \mathrm{hr} \mathrm{Vs} 4^{\text {th }} \mathrm{hr}$ & -0.1000 & 5.941 & Yes & $* *$ & -0.1712 to -0.02876 \\
\hline
\end{tabular}


In Group B (Half the calculated effective dose) and Group C (Calculated effective dose) paw volume reduced significantly after drug administration at $3^{\text {rd }}$ and $4^{\text {th }}$ hour compared to before drug administration. But in Group B at $1^{\text {st }}$ hour a significant increase in paw volume occurred and at $2^{\text {nd }}$ hour an insignificant reduction in the paw volume occurred compared to before drug administration. In Group $\mathrm{C}$ at $1^{\text {st }}$ hour after drug administration paw volume remain unchanged and from $2^{\text {nd }}$ hour onwards significant reduction in paw volume noticed when compared to before drug administration. (Table 3), (Table 4)

Table 3: Comparison of paw volume within Group B (Half the calculated effective dose)

\begin{tabular}{|c|c|c|c|c|c|}
\hline Group B & Mean Diff. & $\mathbf{q}$ & Significance & Summary & $95 \%$ CI of diff \\
\hline BDA Vs $1^{\text {st }} \mathrm{hr}$ & -0.08333 & 4.385 & Yes & $*$ & -0.1638 to -0.002913 \\
\hline BDA Vs $2^{\text {nd }} \mathrm{hr}$ & 0.0 & 0.0 & No & ns & -0.08042 to 0.08042 \\
\hline BDA Vs $3^{\text {rd }} \mathrm{hr}$ & 0.1167 & 6.139 & Yes & $* *$ & 0.03625 to 0.1971 \\
\hline BDA Vs $4^{\text {th }} \mathrm{hr}$ & 0.1333 & 7.016 & Yes & $* * *$ & 0.05291 to 0.2138 \\
\hline $1^{\text {st }} \mathrm{hr}$ Vs $2^{\text {nd }} \mathrm{hr}$ & 0.08333 & 4.385 & Yes & $*$ & 0.002913 to 0.1638 \\
\hline $1^{\text {st }} \mathrm{hr}$ Vs $3^{\text {rd }} \mathrm{hr}$ & 0.2000 & 10.52 & Yes & $* * *$ & 0.1196 to 0.2804 \\
\hline $1^{\text {st }} \mathrm{hr} \mathrm{Vs} 4^{\text {th }} \mathrm{hr}$ & 0.2167 & 11.40 & Yes & $* * *$ & 0.1362 to 0.2971 \\
\hline $2^{\text {nd }} \mathrm{hr} \mathrm{Vs} 3^{\text {rd }} \mathrm{hr}$ & 0.1167 & 6.139 & Yes & $* *$ & 0.03625 to 0.1971 \\
\hline $2^{\text {nd }} \mathrm{hr} \mathrm{Vs}^{\text {th }} \mathrm{hr}$ & 0.1333 & 7.016 & Yes & $* * *$ & 0.05291 to 0.2138 \\
\hline $3^{\text {rd }} \mathrm{hr} \mathrm{Vs} 4^{\text {th }} \mathrm{hr}$ & 0.01667 & 0.8771 & No & $\mathrm{ns}$ & -0.06375 to 0.09709 \\
\hline
\end{tabular}

Table 4: Comparison of paw volume within Group C (Calculated effective dose)

\begin{tabular}{|c|c|c|c|c|c|}
\hline Group C & Mean Diff. & $\mathbf{q}$ & Significance & Summary & 95\% CI of diff \\
\hline BDA Vs $1^{\text {st }} \mathrm{hr}$ & 0.0 & 0.0 & No & ns & -0.08696 to 0.08696 \\
\hline BDA Vs $2^{\text {nd }} \mathrm{hr}$ & 0.1000 & 4.867 & Yes & $*$ & 0.01304 to 0.1870 \\
\hline BDA Vs $3^{\text {rd }} \mathrm{hr}$ & 0.2000 & 9.733 & Yes & $* * *$ & 0.1130 to 0.2870 \\
\hline BDA Vs $4^{\text {th }} \mathrm{hr}$ & 0.2833 & 13.79 & Yes & $* * *$ & 0.1964 to 0.3703 \\
\hline $1^{\text {st }} \mathrm{hr} \mathrm{Vs} 2^{\text {nd }} \mathrm{hr}$ & 0.1000 & 4.867 & Yes & $*$ & 0.01304 to 0.1870 \\
\hline 1 st hr Vs $3^{\text {rd }} \mathrm{hr}$ & 0.2000 & 9.733 & Yes & $* * *$ & 0.1130 to 0.2870 \\
\hline $1^{\text {st }} \mathrm{hr}$ Vs $4^{\text {th }} \mathrm{hr}$ & 0.2833 & 13.79 & Yes & $* * *$ & 0.1964 to 0.3703 \\
\hline $2^{\text {nd }} \mathrm{hr} \mathrm{Vs} 3^{\text {rd }} \mathrm{hr}$ & 0.1000 & 4.867 & Yes & $*$ & 0.01304 to 0.1870 \\
\hline $2^{\text {nd }} \mathrm{hr}$ Vs $4^{\text {th }} \mathrm{hr}$ & 0.1833 & 8.922 & Yes & $* * *$ & 0.09637 to 0.2703 \\
\hline $3^{\text {rd }} \mathrm{hr} \mathrm{Vs} 4^{\text {th }} \mathrm{hr}$ & 0.08333 & 4.056 & No & $\mathrm{ns}$ & -0.003626 to 0.1703 \\
\hline
\end{tabular}

Table 5: Comparison of paw volume within Group D (Double the calculated effective dose)

\begin{tabular}{|c|c|c|c|c|c|}
\hline Group D & Mean Diff. & $\mathbf{q}$ & Significance & Summary & $95 \%$ CI of diff \\
\hline BDA Vs $1^{\text {st }} \mathrm{hr}$ & 0.01667 & 0.8058 & No & ns & -0.07086 to 0.1042 \\
\hline BDA Vs $2^{\text {nd }} \mathrm{hr}$ & 0.1167 & 5.641 & Yes & ** & 0.02914 to 0.2042 \\
\hline BDA Vs $3^{\text {rd }} \mathrm{hr}$ & 0.2333 & 11.28 & Yes & $* * *$ & 0.1458 to 0.3209 \\
\hline BDA Vs $4^{\text {th }} \mathrm{hr}$ & 0.3000 & 14.50 & Yes & $* * *$ & 0.2125 to 0.3875 \\
\hline $1^{\text {st }} \mathrm{hr} V s 2^{\text {nd }} \mathrm{hr}$ & 0.1000 & 4.835 & Yes & $*$ & 0.01247 to 0.1875 \\
\hline $1^{\text {st }} \mathrm{hr} \mathrm{Vs} 3^{\text {rd }} \mathrm{hr}$ & 0.2167 & 10.48 & Yes & $* * *$ & 0.1291 to 0.3042 \\
\hline $1^{\text {st }} \mathrm{hr}$ Vs $4^{\text {th }} \mathrm{hr}$ & 0.2833 & 13.70 & Yes & $* * *$ & 0.1958 to 0.3709 \\
\hline $2^{\text {nd }} \mathrm{hr} V \mathrm{ss} 3^{\text {rd }} \mathrm{hr}$ & 0.1167 & 5.641 & Yes & $* *$ & 0.02914 to 0.2042 \\
\hline $2^{\text {nd }} \mathrm{hr} \mathrm{Vs} 4^{\text {th }} \mathrm{hr}$ & 0.1833 & 8.864 & Yes & $* * *$ & 0.09580 to 0.2709 \\
\hline $3^{\text {rd }} \mathrm{hr} V s 4^{\text {th }} \mathrm{hr}$ & 0.06667 & 3.223 & No & ns & -0.02086 to 0.1542 \\
\hline
\end{tabular}

Difference in paw volume when compared between various groups at before drug administration and at 1 st hour after drug administration were found insignificant (Table 6) (Table 7).

Table 6: Comparison of paw volume between Groups before drug administration

\begin{tabular}{|l|c|c|c|c|c|}
\hline Groups & Mean Diff. & $\mathbf{q}$ & Significance & Summary & $\mathbf{9 5 \%}$ CI of diff \\
\hline Group A Vs Group B & 0.0 & 0.0 & No & ns & -0.1675 to 0.1675 \\
\hline Group A Vs Group C & -0.03333 & 0.7875 & No & ns & -0.2009 to 0.1342 \\
\hline Group A Vs Group D & -0.01667 & 0.3937 & No & ns & -0.1842 to 0.1509 \\
\hline Group B Vs Group C & -0.03333 & 0.7875 & No & ns & -0.2009 to 0.1342 \\
\hline Group B Vs Group D & -0.01667 & 0.3937 & No & ns & -0.1842 to 0.1509 \\
\hline Group C Vs Group D & 0.01667 & 0.3937 & No & ns & -0.1509 to 0.1842
\end{tabular}

Table 7: Comparison of paw volume between Groups at $1^{\text {st }}$ hour

\begin{tabular}{|l|c|c|c|c|c|}
\hline Groups & Mean Diff. & $\mathbf{q}$ & Significance & Summary & $\mathbf{9 5 \%}$ CI of diff \\
\hline Group A Vs Group B & 0.03333 & 0.8687 & No & ns & -0.1185 to 0.1852 \\
\hline Group A Vs Group C & 0.08333 & 2.172 & No & ns & -0.0685 to 0.2352 \\
\hline Group A Vs Group D & 0.1167 & 3.041 & No & ns & -0.0352 to 0.2685 \\
\hline Group B Vs Group C & 0.05000 & 1.303 & No & ns & -0.1019 to 0.2019 \\
\hline Group B Vs Group D & 0.08333 & 2.172 & No & ns & -0.0685 to 0.2352 \\
\hline Group C Vs Group D & 0.03333 & 0.8687 & No & ns & -0.1185 to 0.1852 \\
\hline
\end{tabular}


Greshma P Raj et.al., In vivo anti-inflammatory activity of rhizome of Drynaria quercifolia (L.) J. Sm.

Difference in paw volume at $2^{\text {nd }}$ hour, $3^{\text {rd }}$ hour and $4^{\text {th }}$ hour after drug administration when compared between various groups found highly significant between Group A (control) with all three treated groups. Comparison between treated groups were insignificant in all these time intervals. (Table 8) (Table 9) (Table 10).

Table 8: Comparison of paw volume between Groups at 2nd hour

\begin{tabular}{|l|c|c|c|c|c|}
\hline Groups & Mean Diff. & $\mathbf{q}$ & Significance & Summary & 95\% CI of diff \\
\hline Group A Vs Group B & 0.2000 & 5.477 & Yes & $* *$ & 0.05547 to 0.3445 \\
\hline Group A Vs Group C & 0.2667 & 7.303 & Yes & Y* & 0.1221 to 0.4112 \\
\hline Group A Vs Group D & 0.3000 & 8.216 & Yes & ns & -0.1555 to 0.4445 \\
\hline Group B Vs Group C & 0.06667 & 1.826 & No & ns & -0.04786 to 0.2112 \\
\hline Group B Vs Group D & 0.1000 & 2.739 & No & ns & -0.1112 to 0.2445 \\
\hline Group C Vs Group D & 0.03333 & 0.9129 & No & 0.1779
\end{tabular}

At $3^{\text {rd }}$ hour and $4^{\text {th }}$ hour after drug administration, the paw volume when compared between the various groups shown high significance between Group A and Group B, Group A and Group C, between Group A and Group D $(\mathrm{p}<0.001)($ Table 9) $($ Table 10).

Table 9: Comparison of paw volume between Groups at $3^{\text {rd }}$ hour

\begin{tabular}{|l|c|c|c|c|c|}
\hline Groups & Mean Diff. & $\mathbf{q}$ & Significance & Summary & 95\% CI of diff \\
\hline Group A Vs Group B & 0.4333 & 13.80 & Yes & $* * *$ & 0.3090 to 0.5576 \\
\hline Group A Vs Group C & 0.4833 & 15.39 & Yes & Y* & 0.3590 to 0.6076 \\
\hline Group A Vs Group D & 0.5333 & 16.98 & Yes & ns & -0.4090 to 0.6576 \\
\hline Group B Vs Group C & 0.05000 & 1.592 & No & ns & -0.02429 to 0.1743 \\
\hline Group B Vs Group D & 0.1000 & 3.184 & No & ns & -0.07429 to 0.2243 \\
\hline Group C Vs Group D & 0.05000 & 1.592 & No & 0.1743
\end{tabular}

Table 10: Comparison of paw volume between Groups at $4^{\text {th }}$ hour

\begin{tabular}{|l|c|c|c|c|c|}
\hline Groups & Mean Diff. & q & Significance & Summary & 95\% CI of diff \\
\hline Group A Vs Group B & 0.5500 & 13.53 & Yes & $* * *$ & 0.3891 to 0.7109 \\
\hline Group A Vs Group C & 0.6667 & 16.40 & Yes & $* * *$ & 0.5058 to 0.8276 \\
\hline Group A Vs Group D & 0.7000 & 17.22 & Yes & ns & -0.5391 to 0.8609 \\
\hline Group B Vs Group C & 0.1167 & 2.870 & No & ns & -0.01424 to 0.2776 \\
\hline Group B Vs Group D & 0.1500 & 3.690 & No & ns & -0.1276 to 0.3109 \\
\hline Group C Vs Group D & 0.03333 & 0.8199 & No & 0.1942
\end{tabular}

\section{Discussion}

In control group of anti-inflammatory study a highly significant increase in paw volume was observed at $1 \mathrm{st}$ hour after the administration of distilled water compared to the paw volume before administration of distilled water $(\mathrm{p}<0.001)$. Similar observations were also noted at $2 \mathrm{nd}$, 3rd and 4th hour after distilled water administration $(\mathrm{p}<0.001)$. So in control group a marked increase in paw volume was observed at every hour in the study. Within half the calculated effective dose group, after the administration of drug (0.108 gm/ 200 gm body weight) paw volume increased significantly $(\mathrm{p}<0.05)$ at the 1 st hour compared to the paw volume before drug administration. In 2 nd hour paw volume reduced insignificantly $(p>0.05)$ and became same as the value of before drug administration. There after the paw volume reduced gradually with high significance at 3rd hour $(p<0.01)$ and at 4th hour $(p<0.001)$. This showed that the drug administered in half the calculated effective dose produced a favourable anti-inflammatory action at 3rd hour after administration and its maximum anti-inflammatory action was at 4 th hour after administration compared to before drug administration. After the administration of calculated effective dose (0.216 gm/200 gm body weight) paw volume remained unchanged at the first hour $(\mathrm{p}>0.05)$. At 2 nd hour after drug administration the reduction in paw volume was significant $(p<0.05)$ compared to before drug administration. There after the reduction in paw volume was gradual with high significance at 3rd and at 4th hour after drug administration compared to the paw volume before drug administration $(p<0.001)$. Comparison between the reduced paw volume within the group at 3rd and 4th hour after drug administration was insignificant $(p>0.05)$. This showed that the drug administered in calculated effective dose produced its anti-inflammatory effect at 2 nd hour after administration and maximum effect was at $3 \mathrm{rd}$ and at 4th hour after administration compared to before drug administration. Within double the calculated effective dose group, after administration of drug (0.432 gm/200 gm body weight) paw volume reduced gradually in every 1 hour up to 4th hour compared to the paw volume before drug administration. The reduction in paw volume was insignificant $(p>0.05)$ at 1 st hour and then it became highly significant at 2 nd hour $(\mathrm{p}<0.01)$, at 3rd hour $(\mathrm{p}<0.001)$ and at 4 th hour $(\mathrm{p}<0.001)$ when compared with paw volume before drug administration. Comparison between the reduced paw volume within the group at 3rd and 4th hour after drug administration was insignificant $(p>0.05)$. So that the drug in double the calculated effective dose produced a favourable action at 2 nd hour after administration and maximum anti-inflammatory action at 3rd and at 4th hour after drug administration compared to before drug administration. In experimental animals a highly significant $(p<0.01)$ reduction in paw volume at the shortest time period (2nd hour) occurred after 
administration of the double the calculated effective dose. In all these treated groups a maximum reduction in paw volume with high significance $(\mathrm{p}<0.001)$ noted at 4th hour after drug administration compared to the paw volume before drug administration. When the difference in paw volume compared between various doses at 1st, 2nd, 3rd and 4th hour after drug administration, insignificant results obtained at 1st hour after drug administration. When the difference in paw volume of half the calculated effective dose group compared with the control group highly significant result seen at 2 nd hour $(\mathrm{p}<0.01)$, at 3rd hour $(\mathrm{p}<0.001)$ and at 4 th hour $(\mathrm{p}<0.001)$ after drug administration. When the difference in paw volume in control group compared with calculated effective dose and double the calculated effective dose a highly significant reduction in inflammation was obtained at $2 \mathrm{nd}$, at $3 \mathrm{rd}$ and at 4 th hour after drug administration in $(p<0.001)$. When the difference in paw volume in calculated effective dose group compared with double the calculated effective dose at 3rd hour after drug administration the significance level was found high $(p<0.001)$. These comparisons showed that the double the calculated effective dose is the most effective dose of choorna (powder) of rhizome of Drynaria quercifolia (L.) J. Sm. to produce an anti-inflammatory action. An immediate and sustained reduction in inflammation with high significance was shown by the groups treated with double the calculated effective dose.

Rhizome of the plant contains flavonoids like naringin and quercetin, triterpenoids like friedelin and $\beta$ - amyrin, alkaloids, proteins, saponins, etc (5). The process of inflammation will be reduced by naringin by reducing the expression of signalling factors like interleukin-6 (IL-6), interleukin-8 (IL-8), nuclear factor erythroid 2-related factor 2 (Nrf2), inducible nitric oxide synthase (iNOS), and TNF- $\alpha$ (13).Quercetin inhibits lipopolysaccharide (LPS)-induced TNF- $\alpha$ production in macrophages and inhibits production of cyclooxygenase (COX) and lipoxygenase (LOX) (14). Friedelin can inhibition the synthesis of prostaglandin (15).By suppressing the release of TNF- $\alpha$ or its proinflammatory action $\beta$-amyrin acts as an antiinflammatory agent (16).Beta sitosterol can inhibits the infiltration of inflammatory cells, and the levels of interleukin-4, $\operatorname{IgE}$ and histamine in serum and thus act as an anti-inflammatory agent (17).

\section{Conclusion}

The present study point toward the dose dependent anti-inflammatory activity of internally administered choorna (powder) of rhizome of Drynaria quercifolia (L.) J. Sm. This activity can be due to the presence of anti-inflammatory phytoconstituents like naringin, quercetin, friedelin, betasitosterol, etc. in the rhizome of the plant.

\section{Acknowledgment}

Authors acknowledge Dr T D Sreekumar, Principal Govt. Ayurveda College, Tripunithura for providing all the necessary facilities and infrastructure.
Authors are grateful to all the staffs of the Department of Dravyaguna vijnanam Govt. Ayurveda College Tripunithura. Authors are thankful to breeding section department of College of Veterinary Sciences, Mannuthy, Thrissur for providing enough number of healthy animals for the work.

\section{Reference}

1. Olavi Pelkonen, Qihe Xu, Tai-Ping Fan. Why is Research on Herbal Medicinal Products Important and How Can We Improve Its Quality? J. Tradit. Complement. Med. 2014; 4(1):1-7

2. Linlin Chen, Huidan Deng, Hengmin Cui, Jing Fang, Zhicai Zuo, Junliang Deng, et al. Inflammatory responses and inflammationassociated diseases in organs. Oncotarget 2018; 9(6):7204-18

3. Hendrik Adriaan Van Rheede. Hortus Malabaricus Vol. XII. Department of Publications University of Kerala; Thiruvanathapuram; 2008. 41-43p.

4. Sreeman Namboothiri. Chikitsamajari. 7th edition. Alappuzha; Vidyarambham publications; 2005.412p.

5. Prasanna G, Anuradha R. A Comprehensive Review on Phytopharmacological Activities of Drynaria quercifolia L. IJPPR 2016; 8 (8): 1304-1313.

6. Dhanalekshmi U M, B. Ramya B, Gowri T. and Srinivasan R. Fresh juice of Drynaria quercifolia rhizome for the management of arthritis. IJPSR, 2021; 12(3): 1465-1473. DOI link: http://

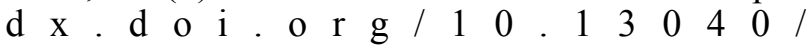
IJPSR.0975-8232.12(3).1465-73

7. Prasanna $G$ and Chitra $M$. In vitro antioxidant activity of Drynaria quercifolia L. Rhizome. IJPSR, 2015; 6(7): 3061-3066. DOI link: http://dx.doi.org/ 10.13040/IJPSR.0975-8232.6(7).3061-66

8. Alam Khan, Ekramul Haque, Mukhlesur Rahman, Ashik Mosaddik, M. Abdul Alim Al-Bari, and Motiur Rahman. Antipyretic Activity of Rhizome of Drynaria quercifolia in Rabbit. Pharma. Biol., 2007; 45(4): 1-4. DOI: 10.1080/13880200701215075

9. Ranjan Padhy, Santosh Kumar Dash. Antibacterial evaluation of methanolic rhizome extract from an in vivo and in vitro grown pteridophyte, Drynaria quercifolia (Linn.) $\mathrm{J}$ smith. Asian $\mathrm{J}$ Pharm Clin Res., $2015 ; 8(4): 130-138$. https:// www.researchgate.net/publication/ 280042950_Ethnomedicinal_plants_used_by_the_tr ibals_of_KälakadMundanthurai_Tiger_Reserve_K MTR_Western_Ghats_Tamil_Nadu_for_the treatm ent_of_rheumatism

10. Banani Das, Manabendra Dutta Choudhury, Amitabha Dey, Anupam Das Talukdar, Kh. Nongalleima, Lokesh Deb. Antioxidant and antiinflammatory activity of aqueous and methanolic extracts of rhizome part of Drynaria quercifolia (L.) J. Smith. Int J Pharm Pharm. Sci, 2014; 6(6): 43-49. https://innovareacademics.in/journal/ijpps/ Vol6Issue6/7679.pdf 
11. Prabhakar Rao G. Sarangadhara Samhitha of Acharya Sarangadhara. 1st edition. New Delhi; Choukambha publications; 2013. 50-53p.

12. Ghosh M. N. Fundamentals of Experimental Pharmacology. $6^{\text {th }}$ edition. Kolkata; Hilton \& Company; 2015.173p.

13. Rui Chen, Qiao-Ling Qi, Meng-Ting Wang, Qi-Yan Li. Therapeutic potential of naringin: an overview. Pharm. Biol. 2016; 54 (12): 3203-3210.

14. Yao Li, Jiaying Yao, Chunyan Han, Jiaxin Yang, Maria Tabassum Chaudhry, Shengnan Wang, Hongnan Liu et al. Quercetin, Inflammation and Immunity. Nutrients 2016; 8(3):167. doi: 10.3390/ nu8030167

15. Paulrayer Antonisamy, Veeramuthu Duraipandiyan, Savarimuthu Ignacimuthu. Anti-inflammatory, analgesic and antipyretic effects of friedelin isolated from Azima tetracantha Lam. in mouse and rat model. J. Pharm. Pharmacol. 2011; 63: 1070-1077. DOI: $10.1111 / j .2042-7158.2011 .01300 . x$

16. Holanda Pinto S. A., Pinto L. M. S., Cunha G. M. A., Chaves M. H., Santos F. A., Rao V. S. Antiinflammatory effect of a, b-Amyrin, a pentacyclic triterpene from Protium heptaphyllum in rat model of acute periodontitis. Inflammopharmacology. 2008; 48-52

17. Rogelio Paniagua-Perez, Gabriela FloresMondragon, Celia Reyes-Legorreta, Brigida Herrera Lopez, Isabel Cervantes-Hernandez, Osiris Madrigal-Santillan, Jose Antonio MoralesGonazalez, Isela A;varez-Gonzalez, Eduardo Madrigal-Bujaidar. Evaluation of the antiinflammatory capacity of beta-sitosterol in rodent assays. Afr. J. Tradit. Complement. Altern. Med. 2017; 14 (1): 123-130. DOI: 10.21010/ ajtcam.v14i1.13 